\title{
Ecological optima and tolerances of coastal benthic diatoms in the freshwater-mixohaline zone of the Río de la Plata estuary
}

\author{
M. Licursi ${ }^{*}$ N. Gómez, J. Donadelli \\ Instituto de Limnología ‘Dr. Raúl A. Ringuelet', UNLP-CONICET (CCT La Plata), CC 712, 1900 La Plata, Argentina
}

\begin{abstract}
The purpose of this study was to explore the autecology of diatom species inhabiting the epipsammon and epiphyton in the freshwater-mixohaline zone of the Río de la Plata estuary. The diatoms are a conspicuous component of those communities. We discuss the optima and tolerance ranges of diatoms for the following environmental variables: conductivity, turbidity, $\mathrm{pH}$, nutrients (phosphate, nitrate, nitrite, and ammonium), and dissolved oxygen levels as well as both the chemical and biological oxygen demand. The study was carried out on the Argentinean coastline between $34^{\circ} 27^{\prime} \mathrm{S}, 58^{\circ} 30^{\prime} \mathrm{W}$ and $35^{\circ} 23^{\prime} \mathrm{S}, 57^{\circ} 08^{\prime} \mathrm{W}$. In total, 32 sampling sites influenced by different land uses were monitored along $168 \mathrm{~km}$ of shoreline. Epipsammic samples of the intertidal zone were taken at low tide during spring 2005, autumn and winter 2006, spring and summer 2007, and autumn 2008. Epiphytic samples were taken during summer, autumn, and spring 2000 and spring 2002. In total, 224 benthic species were identified in the 120 samples analyzed; 81 species had a frequency greater than $5 \%$ in the total sample dataset with more than $1 \%$ of relative abundance in at least 1 sample and were chosen for estimation of their optima and tolerances for selected water-quality characteristics. The physicochemical data analyzed indicated 2 gradients -increases in conductivity and turbidity along with decreases in the concentration of nutrients and organic matter-that generated different types of habitats for the species investigated.
\end{abstract}

KEY WORDS: Diatoms · Optima · Tolerance range · Autecology · Epipsammon · Epiphyton · Coastal-plain estuary $\cdot$ Río de la Plata

\section{INTRODUCTION}

Estuaries, commonly regarded as intermediate transitional zones linking freshwater and marine systems, encompass a wide variety of environments. Estuaries are biologically rich regions where the great variety of habitats contributes to a high productivity in these ecosystems. Human populations have used estuaries as food sources and places of settlement, navigation, and waste repositories. As a result, coastal waters have received large inputs of nutrients, organic matter, and other contaminants. Moreover, habitat destruction, over fishing, wetland loss, and the introduction of nonindigenous species are among the further consequences of the presence of many human activities (Ohrel \& Register 2006).
Diatoms are an important and often dominant component of the benthic microalgal assemblage in estuarine and shallow coastal environments (Admiraal 1984). Diatom taxa occurring in transitional zones between marine and freshwater habitats can be divided into 2 affinity groups, each containing taxa with either a marine or a freshwater affinity (Snoeijs 1999).

When using organisms as indicators of environmental quality, the essential aspect to be considered is that of the ambient conditions affecting the survival, occurrence, abundance, growth, and fecundity of the constituent organisms (Snoeijs 1999). Diatoms are particularly useful as indicators within estuarine systems for the same reason that they are useful in other aquatic habitats and in paleo-ecological studies (Clarke et al. 2006). Each species has characteristic 
optima and tolerances for various aspects of water quality such as $\mathrm{pH}$, salinity, temperature, nutrients, and light availability (i.e. turbidity; Cooper 1995). In a freshwater ecosystem, the dependence of benthic diatoms on nutrients has been so unequivocally clarified that microalgae have been classified according to trophic and saprobity classes and are thus used as sensitive indicators of water quality (Sládeček 1973, 1985, Lange-Bertalot 1979, Hoffman 1994, Van Dam et al. 1994, Gómez \& Licursi 2001, Licursi \& Gómez 2002). Although considerable progress has been made in utilizing diatoms to assess water quality in freshwater systems, the situation is quite different in estuarine and shallow marine coastal systems, particularly in the southern hemisphere (Sullivan 1999).

Nevertheless, diatoms have been widely used in the reconstruction of the paleoenvironment (Cooper 1999, Denys \& de Wolfs 1999, Clarke et al. 2006), and an understanding of modern ecological data can contribute to an improved knowledge of the local habitat. According to Clarke et al. (2006), diatoms are powerful paleoecological indicators, since their taxonomically distinct frustules allow identification to species level, and they are usually present in diverse, numerically abundant assemblages (Charles et al. 1994) that preserve well in a variety of sedimentary environments (Anderson \& Vos 1992). In spite of diatoms having been used largely as indicators of environmental change in marine systems (Stoermer \& Smol 1999) and as indicators of eutrophication in coastal waters (Cooper 1995, Clarke et al. 2006), the current lack of precise autecological knowledge for many coastal taxa makes interpretation of bioestratigraphic records difficult (Clarke et al. 2006). A combination of research, monitoring, and paleoecological studies can become a synergistic tool for discerning the trends, causes, and consequences of watershed-land use (Cooper 1999). Along the Argentinean coast, information about modern diatom distribution is scarce and fragmentary (Hassan et al. 2009); consequently, the majority of diatom-based paleoenvironmental reconstructions have been derived from autecological data extrapolated from the European literature.

The purpose of this study was to explore the autecology of diatom species that inhabit the epipsammon and epiphyton from the freshwater-estuarine zone of the Río de la Plata estuary. Diatoms are a conspicuous component of those communities (Gómez et al. 2003, 2009). Here we discuss the ecological optima and tolerance ranges of diatoms for the following environmental variables: conductivity, turbidity, $\mathrm{pH}$, nutrients (phosphate, nitrate, nitrite, and ammonium), dissolved oxygen (DO) levels, and both the chemical and biological oxygen demand (COD and $\mathrm{BOD}_{5}$, respectively). The overall goal was to provide baseline information for future water-quality assessments as well as for ecological interpretation.

\section{MATERIALS AND METHODS}

Study area. The Río de la Plata is located on the east coast of South America and is a shallow, large-scale, turbid coastal-plain estuary that covers an approximate area of $35000 \mathrm{~km}^{2}$. The inner region has a pluvial

Table 1. Sampling sites, geographical location, and the main land uses in the study area. U: urban, R: recreational, W: waste effluent, F: fishing, I: industrial effluent, H: harbor, $\mathrm{P}$ : water pumping

\begin{tabular}{|c|c|c|c|}
\hline Code & Site name & Coordinates & $\begin{array}{c}\text { Main land } \\
\text { uses }\end{array}$ \\
\hline S1 & Desembocadura de Luján & $34^{\circ} 27^{\prime} 10^{\prime \prime} \mathrm{S}, 58^{\circ} 30^{\prime} 21^{\prime \prime} \mathrm{W}$ & $\mathrm{U}, \mathrm{R}$ \\
\hline S2 & San Isidro & $34^{\circ} 29^{\prime} 08^{\prime \prime} \mathrm{S}, 58^{\circ} 28^{\prime} 49^{\prime \prime} \mathrm{W}$ & $\mathrm{U}, \mathrm{R}$ \\
\hline S3 & Aeroparque-Palermo & $34^{\circ} 32^{\prime} 57^{\prime \prime} \mathrm{S}, 58^{\circ} 25^{\prime} 35^{\prime \prime} \mathrm{W}$ & $\mathrm{U}, \mathrm{R}, \mathrm{P}$ \\
\hline S4 & Costanera Sur & $34^{\circ} 36^{\prime} 54^{\prime \prime} \mathrm{S}, 58^{\circ} 20^{\prime} 24^{\prime \prime} \mathrm{W}$ & $\mathrm{R}$ \\
\hline S5 & Canal Sarandí & $34^{\circ} 39^{\prime} 31^{\prime \prime} \mathrm{S}, 58^{\circ} 18^{\prime} 59^{\prime \prime} \mathrm{W}$ & $\mathrm{U}, \mathrm{W}, \mathrm{I}$ \\
\hline S6 & Canal Santo Domingo & $34^{\circ} 40^{\prime} 01^{\prime \prime} \mathrm{S}, 58^{\circ} 18^{\prime} 04^{\prime \prime} \mathrm{W}$ & $\mathrm{U}, \mathrm{W}, \mathrm{I}$ \\
\hline S7 & Bernal & $34^{\circ} 41^{\prime} 30^{\prime \prime} \mathrm{S}, 58^{\circ} 15^{\prime} 14^{\prime \prime} \mathrm{W}$ & $\mathrm{U}, \mathrm{R}, \mathrm{P}$ \\
\hline S8 & Quilmes & $34^{\circ} 42^{\prime} 31^{\prime \prime} \mathrm{S}, 58^{\circ} 13^{\prime} 30^{\prime \prime} \mathrm{W}$ & $\mathrm{U}, \mathrm{R}$ \\
\hline S9 & Berazategui & $34^{\circ} 44^{\prime} 38^{\prime \prime} \mathrm{S}, 58^{\circ} 10^{\prime} 42^{\prime \prime} \mathrm{W}$ & $\mathrm{W}$ \\
\hline S10 & Boca Cerrada & $34^{\circ} 46^{\prime} 49^{\prime \prime} \mathrm{S}, 58^{\circ} 00^{\prime} 59^{\prime \prime} \mathrm{W}$ & $\mathrm{R}, \mathrm{F}$ \\
\hline S11 & Punta Lara & $34^{\circ} 49^{\prime} 29^{\prime \prime} \mathrm{S}, 57^{\circ} 57^{\prime} 35^{\prime \prime} \mathrm{W}$ & $\mathrm{R}, \mathrm{P}$ \\
\hline $\mathrm{S} 12$ & Puerto La Plata & $34^{\circ} 50^{\prime} 01^{\prime \prime} \mathrm{S}, 57^{\circ} 52^{\prime} 50^{\prime \prime} \mathrm{W}$ & $\mathrm{H}$ \\
\hline $\mathrm{S} 13$ & Los Borrachos & $34^{\circ} 51^{\prime} 17^{\prime \prime} \mathrm{S}, 57^{\circ} 50^{\prime} 21^{\prime \prime} \mathrm{W}$ & $\mathrm{R}, \mathrm{F}$ \\
\hline S14 & Bagliardi & $34^{\circ} 52^{\prime} 26^{\prime \prime} \mathrm{S}, 57^{\circ} 48^{\prime} 33^{\prime \prime} \mathrm{W}$ & W \\
\hline S15 & Balandra & $34^{\circ} 55^{\prime} 44^{\prime \prime} \mathrm{S}, 57^{\circ} 42^{\prime} 56^{\prime \prime} \mathrm{W}$ & $\mathrm{R}$ \\
\hline S16 & Punta Blanca & $34^{\circ} 56^{\prime} 31^{\prime \prime} \mathrm{S}, 57^{\circ} 40^{\prime} 20^{\prime \prime} \mathrm{W}$ & $\mathrm{R}$ \\
\hline S17 & El Pino & $34^{\circ} 57^{\prime} 14^{\prime \prime} \mathrm{S}, 57^{\circ} 38^{\prime} 58^{\prime \prime} \mathrm{W}$ & $\mathrm{R}$ \\
\hline S18 & Campos de Alberdi & $34^{\circ} 58^{\prime} 31^{\prime \prime} \mathrm{S}, 57^{\circ} 37^{\prime} 04^{\prime \prime} \mathrm{W}$ & $\mathrm{R}$ \\
\hline S19 & Atalaya & $35^{\circ} 00^{\prime} 49^{\prime \prime} \mathrm{S}, 57^{\circ} 32^{\prime} 07^{\prime \prime} \mathrm{W}$ & $\mathrm{R}$ \\
\hline S20 & Marcelo & $35^{\circ} 01^{\prime} 16^{\prime \prime} \mathrm{S}, 57^{\circ} 31^{\prime} 13^{\prime \prime} \mathrm{W}$ & $\mathrm{R}$ \\
\hline S21 & Magdalena & $35^{\circ} 01^{\prime} 50^{\prime \prime} \mathrm{S}, 57^{\circ} 29^{\prime} 38^{\prime \prime} \mathrm{W}$ & $\mathrm{R}$ \\
\hline S22 & Juncal 1 & $35^{\circ} 01^{\prime} 39^{\prime \prime} \mathrm{S}, 57^{\circ} 30^{\prime} 22^{\prime \prime} \mathrm{W}$ & $\mathrm{R}$ \\
\hline S23 & Juncal 2-1 & $35^{\circ} 02^{\prime} 22^{\prime \prime} \mathrm{S}, 57^{\circ} 30^{\prime} 01^{\prime \prime} \mathrm{W}$ & $\mathrm{R}$ \\
\hline S24 & Juncal 2-2 & $35^{\circ} 02^{\prime} 00^{\prime \prime} \mathrm{S}, 57^{\circ} 29^{\prime} 57^{\prime \prime} \mathrm{W}$ & $\mathrm{R}$ \\
\hline S25 & Playa nueva & $35^{\circ} 02^{\prime} 08^{\prime \prime} \mathrm{S}, 57^{\circ} 29^{\prime} 44^{\prime \prime} \mathrm{W}$ & $\mathrm{R}$ \\
\hline S26 & Gauchito Gil & $35^{\circ} 02^{\prime} 22^{\prime \prime} \mathrm{S}, 57^{\circ} 29^{\prime} 28^{\prime \prime} \mathrm{W}$ & $\mathrm{R}$ \\
\hline S27 & Ricardo & $35^{\circ} 03^{\prime} 44^{\prime \prime} \mathrm{S}, 57^{\circ} 27^{\prime} 36^{\prime \prime} \mathrm{W}$ & $\mathrm{R}$ \\
\hline S28 & Juan Blanco & $35^{\circ} 05^{\prime} 20^{\prime \prime} \mathrm{S}, 57^{\circ} 25^{\prime} 37^{\prime \prime} \mathrm{W}$ & $\mathrm{R}$ \\
\hline S29 & Pearson & $35^{\circ} 07^{\prime} 27^{\prime \prime} \mathrm{S}, 57^{\circ} 22^{\prime} 53^{\prime \prime} \mathrm{W}$ & $\mathrm{R}$ \\
\hline S30 & Sarandí Sur & $35^{\circ} 12^{\prime} 57^{\prime \prime} \mathrm{S}, 57^{\circ} 17^{\prime} 07^{\prime \prime} \mathrm{W}$ & $\mathrm{R}$ \\
\hline S31 & Punta Indio & $35^{\circ} 16^{\prime} 45^{\prime \prime} \mathrm{S}, 57^{\circ} 13^{\prime} 19^{\prime \prime} \mathrm{W}$ & $\mathrm{R}$ \\
\hline S32 & Punta Piedras & $35^{\circ} 23^{\prime} 28^{\prime \prime} \mathrm{S}, 57^{\circ} 08^{\prime} 50^{\prime \prime} \mathrm{W}$ & $\mathrm{R}$ \\
\hline
\end{tabular}




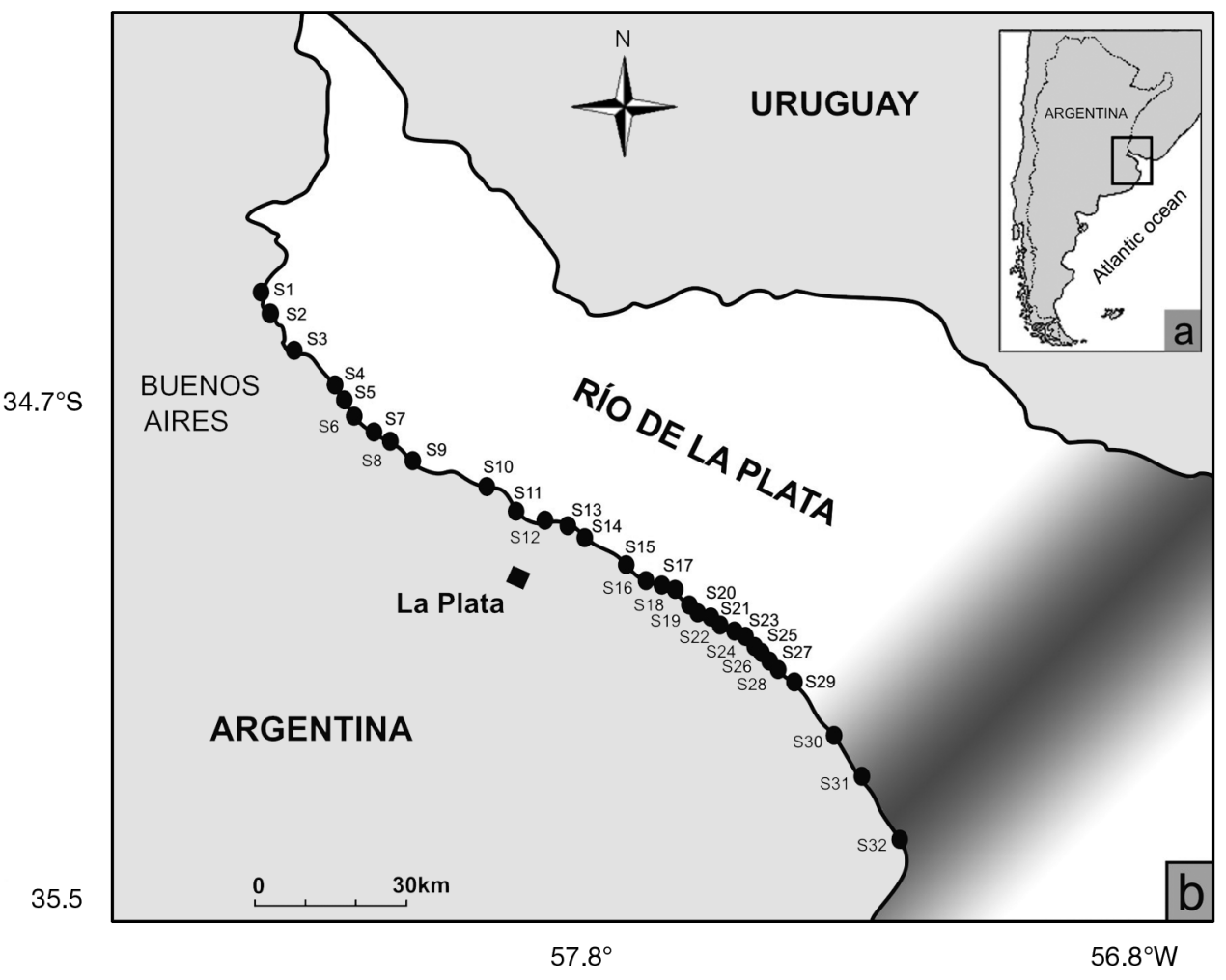

Fig. 1. Study area. (a) Río de la Plata estuary and (b) sampling sites. Shaded area corresponds to the maximum turbidity front

regime with a depth range between 1 and $5 \mathrm{~m}$. The outer region is mainly mixohaline, and the depth ranges between 5 and $25 \mathrm{~m}$. The isohaline region of 0.5 practical salinity units (psu) constitutes the boundary between the freshwater and mixohaline zones (Mianzan et al. 2001). This study was carried out on the Argentinean coastline between coordinates $34^{\circ} 27^{\prime} \mathrm{S}$, $58^{\circ} 30^{\prime} \mathrm{W}$ and $35^{\circ} 23^{\prime} \mathrm{S}, 57^{\circ} 08^{\prime} \mathrm{W}$ (Fig. 1). A total of 32 sampling sites were selected along $168 \mathrm{~km}$ of shoreline in locations influenced by different land uses, as summarized in Table 1. The northernmost sites (S1 to S8) were exposed directly to the impact of the city of Buenos Aires and neighboring towns. Site S9 was located close to the sewage effluent of Buenos Aires. Site S10 was situated in the natural reserve Selva Marginal de Punta Lara. Sites S11 to S14 were located in the surrounding area of the city of La Plata. The remaining sampling sites were exposed to small-scale recreational and fishing activities, and sites S29 to S32 were the closest to the maximum turbidity front of the estuary (Fig. 1). The sediment composition in the study area consisted mainly of both fine and very fine sand (Gómez et al. 2009). Along the coastline, the perennial and littoral helophyte with rhizomes Scirpus californicus (Mey) Steud is frequent.
Sampling and laboratory analysis. Epipsammic samples of the intertidal zone were taken at low tide during spring 2005, autumn and winter 2006, spring and summer 2007, and autumn 2008. At each site, 5 replicates of the surface layer $(0.5 \mathrm{~cm})$ were collected with a core (area: $3.14 \mathrm{~cm}^{2}$ ) for diatom taxonomic identifications and counts and transferred to formalin (final concentration, $4 \% \mathrm{v} / \mathrm{v}$ ) for preservation. Epiphytic samples were taken during summer, autumn, and spring 2000 and in spring 2002. Ten stems of the bulrush Scirpus californicus were cut randomly, and the bottom $15 \mathrm{~cm}$ were retained and transferred to a flask with distilled water. The biofilm was removed by brushing, thus combining the material collected at each sampling site, and likewise preserved in formalin (Gómez et al. 2003). Diatoms were cleaned with $\mathrm{H}_{2} \mathrm{O}_{2}$, washed thoroughly with distilled water, and mounted on microscope slides with Naphrax®. Three hundred valves from each sample were identified under an Olympus BX 51 microscope with either interference, phase-contrast, or Nomarski differential interference contrast (DIC) optics. The following keys were used for species identification: Krammer \& Lange-Bertalot (1986, 1988, 1991a,b), Patrick \& Reimer (1966, 1975), Krammer (1992, 2000), 
and Frenguelli (1941). The conductivity (Lutron 4303CD), DO levels (Oxymeter 600-ESD), turbidity (Turbidity Meter 800-ESD), temperature, and pH (Hanna $\mathrm{HI}$ 8633) were measured in situ. Water samples were also collected to analyze $\mathrm{N}-\mathrm{NH}_{4}{ }^{+}, \mathrm{N}-\mathrm{NO}_{2}{ }^{-}, \mathrm{N}-\mathrm{NO}_{3}{ }^{-}, \mathrm{P}-$ $\mathrm{PO}_{4}{ }^{-3}, \mathrm{BOD}_{5}$, and COD (Mackereth et al. 1978, APHA 1998). Nutrient concentrations are expressed as mg $\mathrm{l}^{-1}$ (for civil servant organizations) and are also given as $\mu \mathrm{mol} \mathrm{l}^{-1}$ (scientific notation) in the supplement at www.int-res.com/articles/suppl/m418p105_supp.pdf.

Data analysis. We excluded all planktonic species from the diatom counts and calculated relative abundance of the benthic diatoms exclusively. For statistical analysis and optimum and tolerance estimations, only those species present in at least $5 \%$ of the total sample dataset and with more than $1 \%$ of relative abundance in at least 1 sample were included.

For the optima and tolerance determination, environmental variables (except $\mathrm{pH}$ ) were log-transformed to approximate a normal distribution.

Canonical correspondence analysis (CCA) was employed to explore the relationship between species composition and the environmental variables measured. When the gradient length (in standard deviation units) in a preliminary detrended correspondence analysis exceeds 2 units, unimodal species response curves could be expected and, subsequently, ordination techniques based on weighted averaging are recommended (Muylaert et al. 2000). Species abundance data were ln transformed. Environmental data were standardized, and only those variables with a variance inflation factor $<10$ were retained in the analysis, because a greater value would indicate multicollinearity among variables (ter Braak \& Verdonschot 1995). Epiphytic samples were not considered for this analysis due to the lack of some environmental data. Samples with extreme environmental values were also excluded. The overall significance of the ordination and the significance of the first axis were tested with a Monte Carlo permutation test $(\mathrm{p}<0.01)$ using restricted permutations.

Weighted average estimates of the species optima $\left(u_{k}\right)$ were calculated, considering abundance of the species in each sample, according to Potapova \& Charles (2003) as

$$
u_{k}=\sum_{i=1}^{n} y_{i k} x_{i} / \sum_{i=1}^{n} y_{i k}
$$

where $y_{i k}$ is the relative abundance of species $k$ in the sample $i_{i} x_{i}$ is the value of the environmental parameter in sample $i_{\text {; }}$ and $n$ is the total number of samples in the dataset. Tolerance or weighted SD $\left(t_{k}\right)$ was calculated according to Potapova \& Charles (2003) as:

$$
t_{k}=\sqrt{\frac{\sum_{i=1}^{n} y_{i k}\left(x_{i}-u_{k}\right)^{2}}{\sum_{i=1}^{n} y_{i k}}}
$$

Pearson correlations were performed to explore the relationship between the relative abundance of diatom species and environmental variables measured. Correlations with a $\mathrm{p}<0.05$ are reported in the text.

\section{RESULTS}

\section{Water quality and diatom assemblage}

The physicochemical parameters employed for the estimation of optima and tolerances of the diatom species are shown in Table 2 . In $52 \%$ of the samples analyzed, the conductivity was $<500 \mu \mathrm{S} \mathrm{cm}^{-1}(<0.3 \mathrm{psu})$, in $25 \%$ it was between 500 and $1000 \mu \mathrm{S} \mathrm{cm}^{-1}$ (0.3 to $0.5 \mathrm{psu}$ ), and the remaining values were all $>1000 \mu \mathrm{S} \mathrm{cm}-1$ ( $>0.5 \mathrm{psu}$ ). For turbidity, $75 \%$ of the samples had values $<300$ nephelometrical turbidity units (NTU), 16\% lay between 300 and 600 NTU, while $9 \%$ were $>600$ NTU. The $\mathrm{pH}$ exhibited values of $<7$ in $5 \%$ of the samples, between 7 and 8 in $41 \%$, and higher in the remainder. The concentrations of DO, expressed as a percent of saturation, were $<50 \%$ in $2 \%$ of the samples, between 50 and $100 \%$ in $51 \%$, and above normal saturation in the rest.

For oxygen demand, $20 \%$ of the data gave values of $<3 \mathrm{mg} \mathrm{l}^{-1}$ of $\mathrm{BOD}_{5}, 56 \%$ showed values between 3 and $10 \mathrm{mg} \mathrm{l}^{-1}$, while the remaining values were higher. The COD values were $<10 \mathrm{mg} \mathrm{l}^{-1}$ in $21 \%$ of the observations, between 10 and $20 \mathrm{mg} \mathrm{l}^{-1}$ in $48 \%$, and higher in the rest. The concentrations of $\mathrm{N}^{-\mathrm{NO}_{3}}{ }^{-}$were $<1 \mathrm{mg} \mathrm{l}^{-1}$ $\left(<71.4 \mathrm{\mu mol} \mathrm{l}^{-1}\right)$ in $50 \%$ of the samples, between 1 and $2 \mathrm{mg} \mathrm{l}^{-1}$ (71.4 to $142.8 \mu \mathrm{mol} \mathrm{l} \mathrm{l}^{-1}$ ) in $29 \%$, and above this

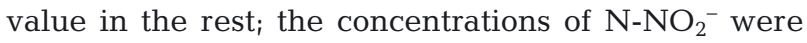
$<0.05 \mathrm{mg} \mathrm{l}^{-1}\left(<3.6 \mu \mathrm{mol} \mathrm{l}^{-1}\right)$ in $60 \%$, between 0.05 and $0.1 \mathrm{mg} \mathrm{l}^{-1}$ (3.6 to $7.1 \mu \mathrm{mol} \mathrm{l} \mathrm{l}^{-1}$ ) in $25 \%$, and $>0.1 \mathrm{mg} \mathrm{l}^{-1}$ $\left(<7.1 \mathrm{~mol} \mathrm{l}^{-1}\right)$ in the remainder. The values of $\mathrm{N}_{-} \mathrm{NH}_{4}{ }^{+}$ were $<0.1 \mathrm{mg} \mathrm{l}^{-1}\left(<7.1 \mu \mathrm{mol} \mathrm{l}^{-1}\right)$ in $40 \%$ of the samples, between 0.1 and $1 \mathrm{mg} \mathrm{l}^{-1}$ (7.1 to $71.4 \mu \mathrm{mol} \mathrm{l}^{-1}$ ) in $51 \%$, and above this value in the rest; and the concentrations of $\mathrm{P}_{-} \mathrm{PO}_{4}{ }^{-3}$ were $<0.1 \mathrm{mg} \mathrm{l}^{-1}\left(<3.2 \mu \mathrm{mol} \mathrm{l}^{-1}\right)$ in $7 \%$ of the samples, between 0.1 and $0.5 \mathrm{mg} \mathrm{l}^{-1}$ (3.2 to $16.1 \mu \mathrm{mol}$ $\mathrm{l}^{-1}$ ) in $80 \%$, and above this value in the remainder.

The first 2 axes of the canonical correspondence analysis accounted for $39 \%$ of the sum of all canonical eigenvalues and were selected for graphical representation (Figs. $2 \& 3$ ). According to this statistical analysis, the nutrients and organic matter exhibited the highest values at sites influenced by anthropogenic activities (S6, S10, S11, S14, S9, and S8). These sampling sites correspond to a diversified use of the 


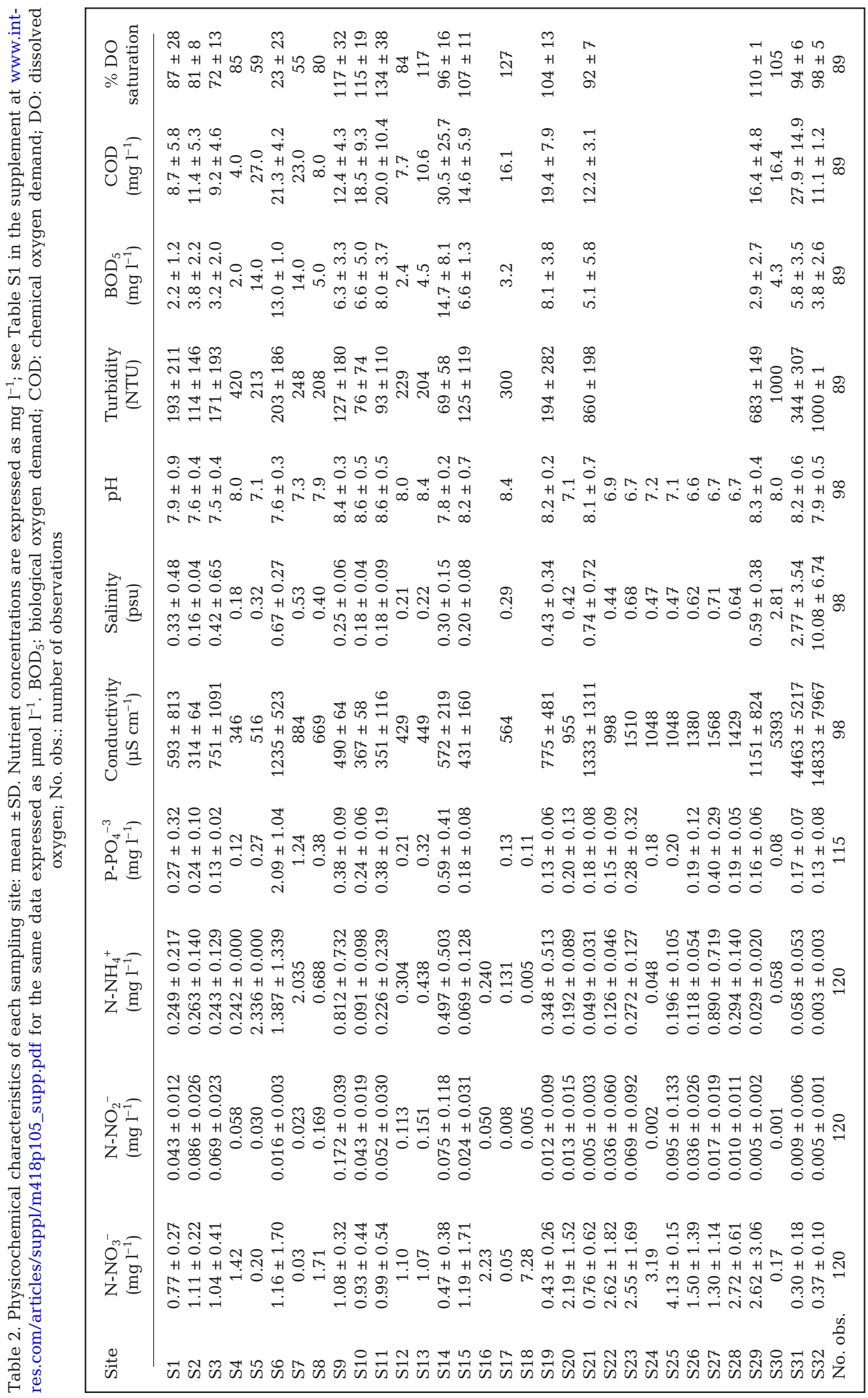


land, mainly urban and waste and industrial effluents (Table 1). The species that were associated with these conditions were, in decreasing order of strength, Nitzschia umbonata, Pinnularia microstauron, N. paleacea, Fragilaria capucina, Sellaphora pupula, Placoneis placentula, Mayamea atomus, Diadesmis contenta, Gomphonema parvulum, N. inconspicua, Achnanthidium minutissimum, Neidium iridis, Sellaphora nyassensis, Nitzschia lacunarum, Geissleria decussis, Planothidium delicatulum, Pseudostaurosira brevistriata, Ulnaria ulna, and Staurosira construens (Fig. 3).

The conductivity and turbidity increased significantly in those sites nearer to the maximum turbidity front: S21, S30, S31, and S32 (Fig. 2). Navicula germainii, N. angusta, Nitzschia filiformis, Tryblionella calida, T. apiculata, Hantzschia virgata, Nitzschia sigma, Staurosirella pinnata, Diadesmis confervacea, and Amphora acutiuscula were linked with these conditions of high turbidity and conductivity (Fig. 3).

\section{Optima and tolerances of diatom species}

Of 224 benthic species identified, 81 had a frequency greater than $5 \%$ of the total sample dataset and more than $1 \%$ of relative abundance in at least 1 sample;

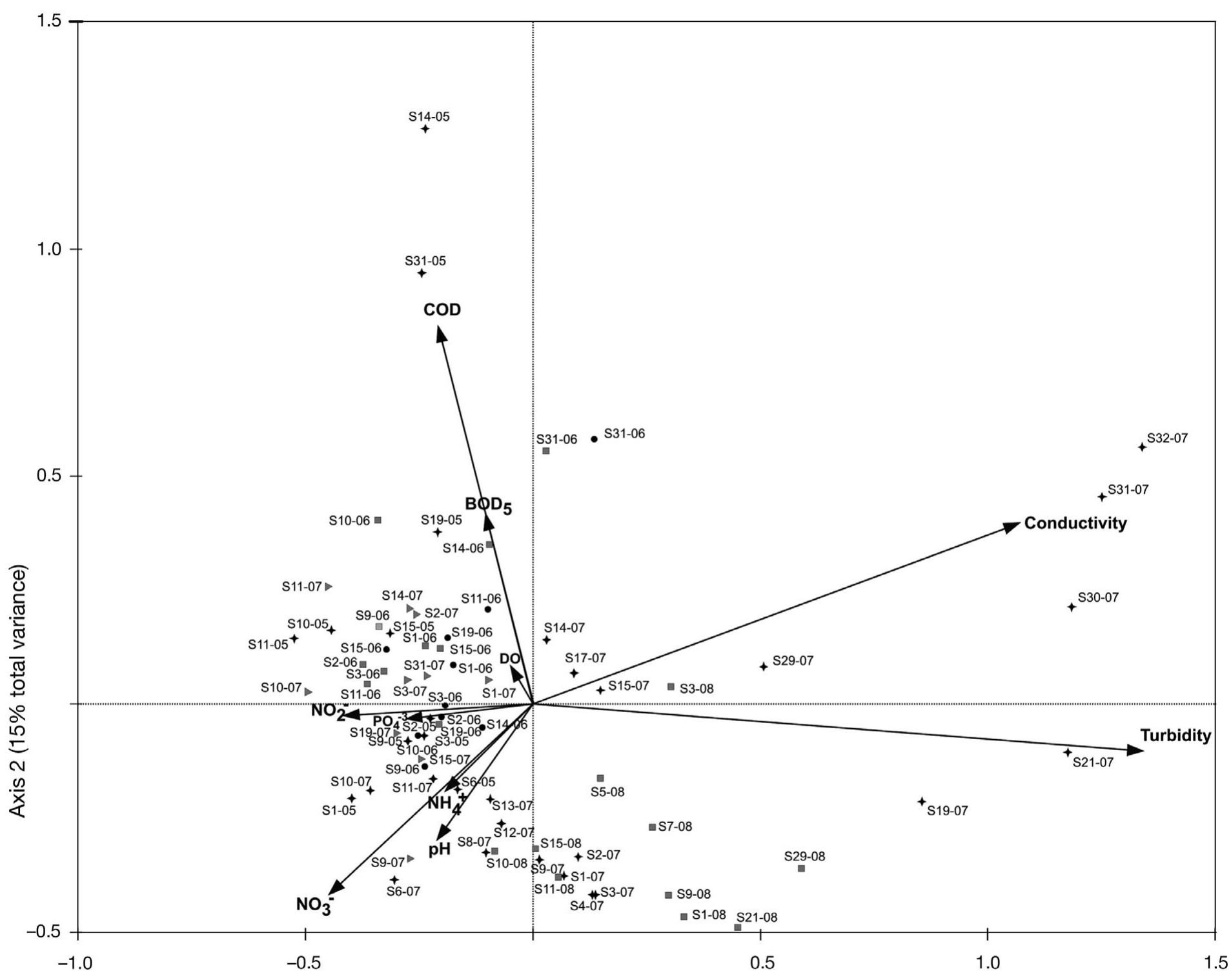

Axis $1(24 \%$ total variance)

Fig. 2. Biplot of the first 2 axes of the canonical correspondence analysis showing environmental variables and sampling sites. Squares: autumn; circles: winter; triangles: summer; stars: spring 
thus they were selected to estimate the optima and tolerances for specific water-quality characteristics (Table 3).

Turbidity and conductivity. Species such as Navicula germainii, N. angusta, Amphora acutiuscula, Tryblionella calida, and T. apiculata were associated with high turbidity (optimum at $>388$ NTU) and conductivity (optimum at $>1643 \mu \mathrm{S} \mathrm{cm} \mathrm{cm}^{-1}$ ), as these species were better represented in the area close to the zone of maximum turbidity of the estuary and their relative abundance exhibited significant correlations with those 2 variables. Among these diatoms, N. germainii was recognized as a taxon with a tight range of tolerance to turbidity. By contrast, in the freshwater sector, species such as Sellaphora nyassensis, Nitzschia lacunarum,
Stauroneis brasiliensis, Craticula accomoda, Neidium iridis, Fragilaria goulardii, and Geissleria decussis were linked with less turbid and mineralized environments (optima at $<67 \mathrm{NTU},<403 \mu \mathrm{S} \mathrm{cm}{ }^{-1}$ ). Among these species, N. lacunarum, C. accomoda, N. iridis, F. goulardii, and $G$. decussis presented a tight range of tolerance to turbidity, while $N$. iridis, C. accomoda, and N. lacunarum did so to conductivity (Table 3).

Inorganic phosphate. The abundances of species such as Nitzschia umbonata, Placoneis placentula, Sellaphora pupula, and Mayamea atomus showed a close correlation with increases in the concentration of $\mathrm{P}$ $\mathrm{PO}_{4}{ }^{-3}$ (optimum at $>0.38 \mathrm{mg} \mathrm{l}^{-1}$ ). Most of the species selected for this study, however, had prevalence optima at concentrations $<0.35 \mathrm{mg} \mathrm{l}^{-1}$, and only the

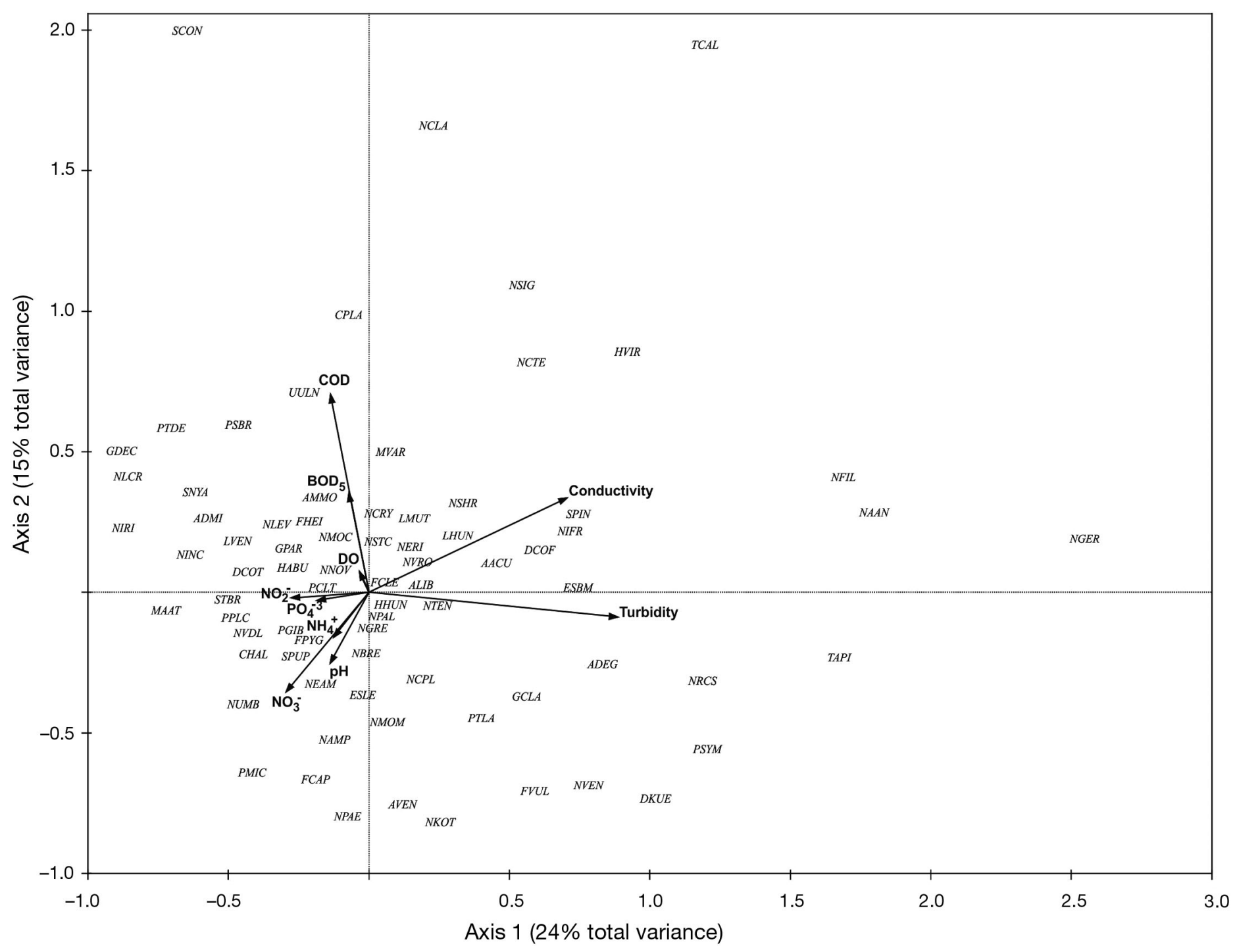

Fig. 3. Biplot of the first 2 axes of the canonical correspondence analysis showing environmental variables and diatom taxa. Acronyms correspond to those in Table 3 


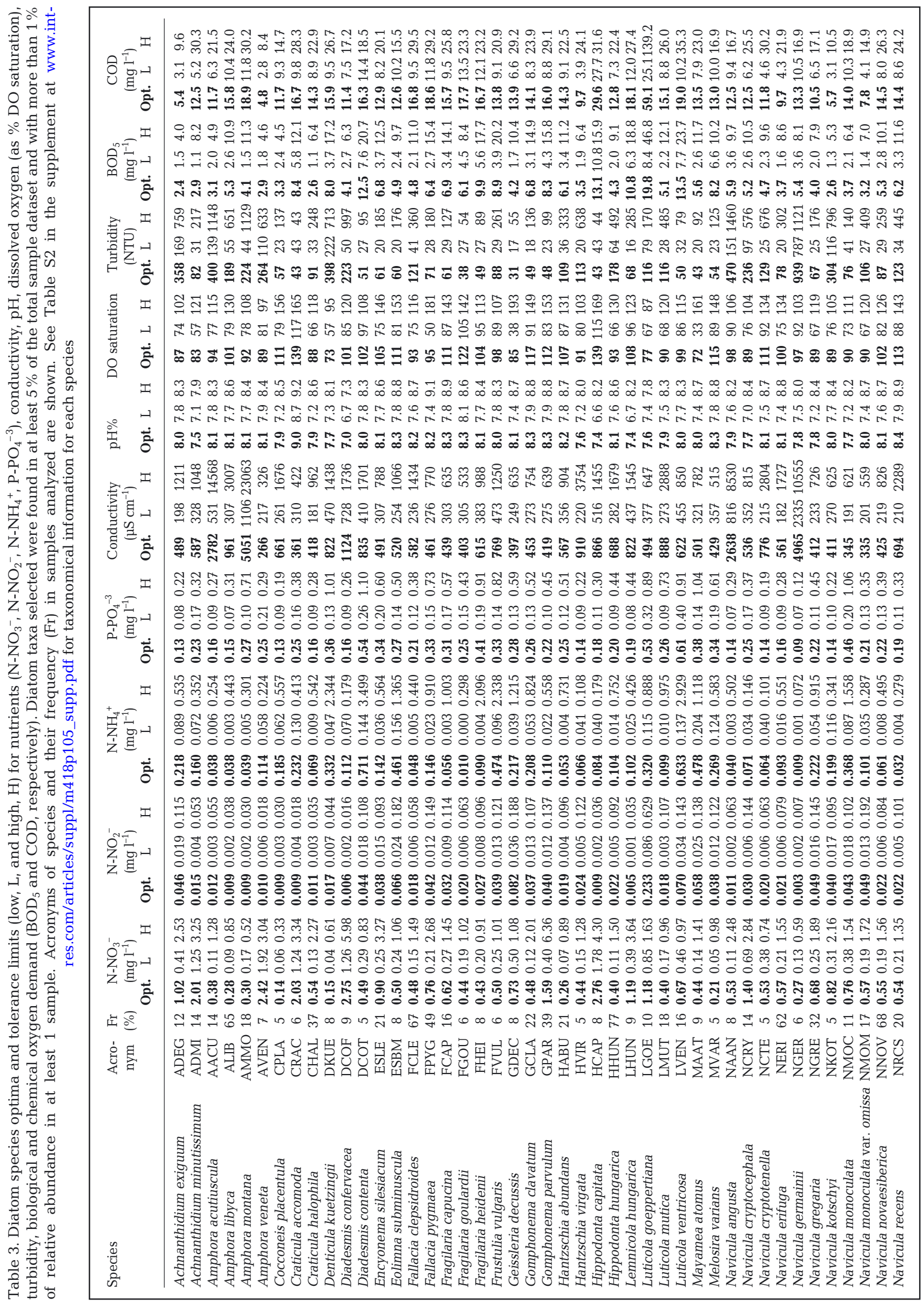




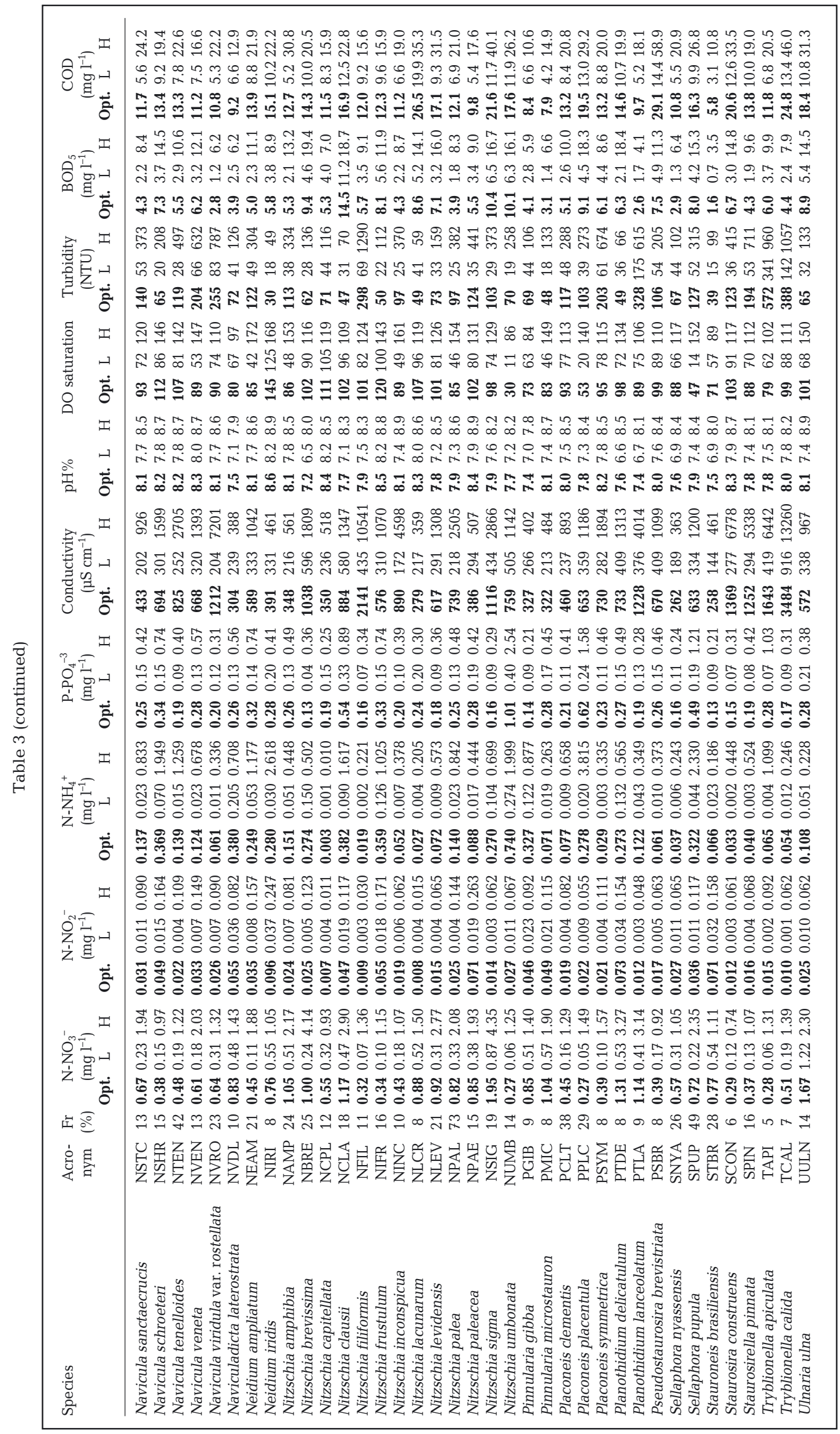


abundance of $A$. libyca presented a significant negative correlation with increases in this anion (Table 3 ).

Inorganic nitrogen. Species such as Diadesmis confervacea, Hippodonta capitata, Gomphonema parvulum, Amphora veneta, Nitzschia sigma, Achnanthidium minutissimum, and Craticula accomoda tolerated concentrations of $\mathrm{N}^{-\mathrm{NO}_{3}}{ }^{-}$higher than $1.59 \mathrm{mg}$ $\mathrm{l}^{-1}$, though none of them presented statistically significant correlations. The rest of the species studied had prevalence optima at lower concentrations, and Melosira varians and Amphora libyca were the only ones whose relative abundance was negatively correlated with this ion (Table 3). With respect to nitrite, the prevalence of species such as Luticola goeppertiana, Neidium iridis, Nitzschia paleacea, and Geissleria decussis was significantly correlated with the highest values of $\mathrm{N}-\mathrm{NO}_{2}^{-}$(optimum at $>0.07 \mathrm{mg} \mathrm{l}^{-1}$ ), while half of the species analyzed exhibited optima lower than $0.02 \mathrm{mg} \mathrm{l}^{-1}$. Among them, A. libyca and Fallacia clepsidroides, 2 species that are widely represented within the area of study, exhibited negative correlations with concentrations of this ion (Table 3). Finally, high concentrations of $\mathrm{N}^{-\mathrm{NH}_{4}}{ }^{+}$were associated with higher relative abundances of Nitzschia umbonata, Placoneis placentula, Neidium iridis, Diadesmis contenta, Denticula kuetzingii, Eolimna subminuscula, Sellaphora pupula, Navicula schoeteri, and Mayamea atomus (optimum at $>0.28 \mathrm{mg} \mathrm{l}^{-1}$ ), with $M$. atomus exhibiting the narrowest tolerance range among them. By contrast, Nitzschia capitellata, Navicula germainii, Navicula cryptotenella, Hantzschia virgata, Nitzschia lacunarum, and Navicula cryptocephala proved more sensitive to increases in the concentrations of this ion (optimum at $<0.07 \mathrm{mg}$ $\mathrm{l}^{-1}$; Table 3).

DO and its demands. The relative abundance of Luticola goeppertiana, Lemnicola hungarica, Nitzschia sigma, Fragilaria heidenii, Placoneis placentula, Ulnaria ulna, and Gomphonema parvulum showed significant correlations with high concentrations of $\mathrm{BOD}_{5}$ (optimum at $>8.3 \mathrm{mg} \mathrm{l}^{-1}$ ), whereas the presence of Stauroneis brasiliensis, Planothidium lanceloatum, Amphora acutiuscula, Craticula halophila, Navicula viridula var. rostellata, and Hippodonta hungarica correlated with much lower concentrations (optimum at $<4.3 \mathrm{mg} \mathrm{l}^{-1}$; Table 3). With respect to the COD, the prevalence of L. goeppertiana, Pseudostaurosira brevistriata, and Nitzschia lacunarum was significantly related to the highest values (optimum at $>26.5 \mathrm{mg} \mathrm{l}^{-1}$ ), and only $N$. lacunarum showed a stringent range of tolerance. At the lower CODs, the presence of Amphora veneta, Achnanthidium exiguum, Navicula kotschyi, Stauroneis brasiliensis, Pinnularia microstauron, and Navicula monoculata var. omissa (optimum at $<7.8 \mathrm{mg}$ $\mathrm{l}^{-1}$ ) was significantly correlated (Table 3 ). The species whose abundances were related to values of oxygen supersaturation were Neidium iridis, Hippodonta capitata, Craticula accomoda, Navicula recens, and Navicula tenelloides, while Nitzschia umbonata, P. placentula, and Sellaphora pupula were related to low oxygen levels (optimum at $<54 \%$ saturation; Table 3 ).

Water pH. Craticula accomoda and Navicula recens were the species associated significantly with more alkaline water (optimum at $>8.4$ ), whereas the presence of Naviculadicta laterostrata, Sellaphora nyassensis, and Staurosirella pinnata showed significant correlations with less alkaline water (with optimum at $<7.8$; Table 3).

\section{DISCUSSION AND CONCLUSION}

The physicochemical data analyzed indicated 2 gradients - increases in conductivity and turbidity along with decreases in the concentration of nutrients and organic matter - that generated different types of habitats for the selected species investigated. On the basis of these gradients, we were able to recognize the optima for the most frequent and abundant species in the study area.

According to the categories proposed by Van Dam et al. (1994) in relation to salinity, $4 \%$ of the species analyzed in this study were freshwater, $68 \%$ freshbrackish water, $13 \%$ brackish-freshwater, and 15\% brackish-water affiliates, with the narrowest tolerance ranges being exhibited by the species found in the area with freshwater characteristics. Our results agree with Carpelan (1978), who indicated that all diatoms living in transitional zones should be considered either marine or freshwater taxa in essence, but with different degrees of euryhalinity. Marine organisms per se were not represented in this study since the species we identified were those habitually associated with the phytobenthos of pampean rivers and streams with different degrees of mineralization (Gómez \& Licursi 2001, Licursi 2005).

The species best adapted to a higher degree of variability in physicochemical conditions-mainly conductivity and turbidity-were Navicula germainii, N. angusta, Amphora acutiuscula, Tryblionella calida, and T. apiculata. Of these species, A. acutiuscula has been previously reported in estuaries of the Argentine coast (Hassan et al. 2009) with salinities ranging from 25 to $31 \mathrm{psu}$, whereas in the present study this species was associated with conditions of lower salinity (with a minimum of $0.37 \mathrm{psu}$ ). In the transitional zone between the upper and lower estuary, the processes associated with the interaction of the river freshwater and the salineshelf water along with the tidal stirring generate a turbidity front in the Río de la Plata whose structure and 
distribution is temporarily variable (Framiñan et al. 1999).

According to Admiraal (1984), possibly one of the most conspicuous ecophysiological characteristics of estuarine benthic diatoms is their extreme versatility towards the wide ranges of physicochemical conditions in their harsh natural habitat. By contrast, in the freshwater sector with more river-like characteristics, Nitzschia lacunarum, Craticula accomoda, and Neidium iridis have been recognized as the species with a tighter range of tolerance for turbidity and conductivity.

Although the whole study area experiences mesoeutrophic conditions (López \& Nagy 2005, Gómez et al. 2009) the species identified were capable of responding to the variations recorded in the ranges of the nutrients. Accordingly, Amphora libyca was associated with less eutrophic conditions, while the presence of Nitzschia umbonata, Placoneis placentula, and Sellaphora pupula was correlated with high concentrations of nutrients. According to Van Dam et al. (1994), A. libyca is a eutrophic species, although our results as well as those reported by Gómez \& Licursi (2001) indicate that this species presents high relative abundances in both mesotrophic to eutrophic environments of pampean rivers and streams and in the Río de la Plata estuary. On the other hand, we found N. umbonata to be the species with the highest relative abundance in environments rich in both ammonia and phosphate, and it was previously reported by Van Dam et al. (1994) to be an obligate nitrogen heterotroph.
On the basis of the oxygen demands recorded in this study and their relationship to different levels of saprobity (Sladecek 1973), $80 \%$ of the sites we analyzed would correspond to appropriate environments for the development of mesosaprobic species. In accordance with these characteristics, $89 \%$ of the species exhibited optima consistent with conditions ranging from $\alpha$-mesosaprobic to polysaprobic. Among the species strongly associated with environments rich in organic matter, we recorded Luticola goeppertiana, Lemnicola hungarica, Nitzschia sigma, Fragilaria heidenii, Placoneis placentula, Ulnaria ulna, and Gomphonema parvulum, whereas the presence of Stauroneis brasiliensis, Planothidium lanceloatum, Amphora acutiuscula, Craticula halophila, and Navicula viridula var. rostellata correlated more closely with oligosaprobic- $\beta$-mesosaprobic environments from the standpoint of their optima. According to the $\mathrm{pH}$-optimum-based classification system proposed by Hustedt (in Battarbee et al. 1999), 89\% of the species sampled were alkalibiontic (optima and tolerances at $\mathrm{pH}$ values $>7$ ), while the remaining were alkaliphilous, with only Diadesmis confervacea exhibiting an optimum at a value close to neutrality (i.e. $\mathrm{pH} 7$ ).

The results obtained in this study have provided new or additional information on certain species where previous data were either lacking or fragmented (Table 4).

Diatom studies of an applied nature in estuaries and shallow coastal waters have been few in number, especially when compared to those dealing with freshwater and the ocean (Sullivan 1999). Further studies are

Table 4. Ecological characteristics of diatom species whose previous information was lacking or fragmented. Obs: observations; NI: new information; AI: additional information

\begin{tabular}{|c|c|c|c|c|c|c|}
\hline \multirow[t]{2}{*}{ Species } & \multicolumn{6}{|c|}{-Ecological characteristic } \\
\hline & Salinity & $\mathrm{pH}$ & Trophic state & Saprobity & Oxygen & Obs. \\
\hline Amphora acutiuscula & & Alkalibiontic & Mesotrophic & $\beta$-mesosaprobic & High & NI \\
\hline Nitzschia lacunarum & Freshwater & Alkalibiontic & Mesotrophic & $\beta$ - $\alpha$-mesosaprobic & High & NI \\
\hline Stauroneis brasiliensis & Freshwater & Alkaliphilous & Oligo-mesotrophic & Oligo-mesosaprobic & Moderate & NI \\
\hline Navicula monoculata var. omissa & Freshwater & & Mesotrophic & $\beta$-mesosaprobic & Moderate to high & NI \\
\hline Fragilaria heidenii & Fresh-brackish water & Alkalibiontic & Eutrophic & $\alpha$-mesosaprobic & Moderate to high & NI \\
\hline Placoneis symmetrica & Brackish-freshwater & Alkalibiontic & Mesotrophic & $\beta$ - $\alpha$-mesosaprobic & Moderate to high & NI \\
\hline Navicula sanctaecrucis & Fresh-brackish water & Alkalibiontic & Mesotrophic & $\beta$ - $\alpha$-mesosaprobic & Moderate to high & NI \\
\hline Planothidium delicatulum & Fresh-brackish water & Alkaliphilous & Mesotrophic & $\alpha$-mesosaprobic & Moderate to high & NI \\
\hline Fragilaria goulardii & Freshwater & Alkalibiontic & Mesotrophic & $\beta$ - $\alpha$-mesosaprobic & Moderate to high & NI \\
\hline Tryblionella calida & Brackish water & Alkalibiontic & Oligo-mesotrophic & $\beta$-mesosaprobic & Moderate to high & NI \\
\hline Hantzschia virgata & Brackish water & Alkalibiontic & Oligotrophic & $\beta$-mesosaprobic & Moderate to high & NI \\
\hline Fallacia clepsidroides & Brackish-freshwater & Alkalibiontic & Mesotrophic & $\beta$ - $\alpha$-mesosaprobic & Moderate to high & NI \\
\hline Navicula erifuga & & Alkalibiontic & Oligo-mesotrophic & $\beta$-mesosaprobic & Moderate to high & $\mathrm{AI}$ \\
\hline Navicula recens & & Alkalibiontic & Oligo-mesotrophic & $\beta$ - $\alpha$-mesosaprobic & Moderate to high & $\mathrm{AI}$ \\
\hline Neidium ampliatum & & Alkalibiontic & & $\beta$ - $\alpha$-mesosaprobic & Moderate to high & $\mathrm{AI}$ \\
\hline Fragilaria capucina & Freshwater & Alkalibiontic & & $\alpha$-mesosaprobic & Moderate to high & $\mathrm{AI}$ \\
\hline Nitzschia capitellata & Fresh-brackish water & Alkalibiontic & Oligo-mesotrophic & $\beta$-mesosaprobic & Moderate to high & $\mathrm{AI}$ \\
\hline Naviculadicta laterostrata & Freshwater & & Mesotrophic & $\beta$-mesosaprobic & Moderate to high & $\mathrm{AI}$ \\
\hline Navicula kotschyi & & Alkalibiontic & Oligo-mesotrophic & $\beta$-mesosaprobic & Moderate to high & $\mathrm{AI}$ \\
\hline Navicula cryptotenella & & Alkalibiontic & Oligo-mesotrophic & & Moderate to high & $\mathrm{AI}$ \\
\hline
\end{tabular}


therefore needed in the future that are aimed at determining the tolerance of benthic diatoms to various forms of pollution in order to formulate accurate waterquality indices for estuaries.

The determination of the optimum and tolerance range of a species to major environmental variables that are exposed is a valuable tool to establish its indicator value and its use as a biomonitor in aquatic ecosystems. The results of this study show that diatoms identified in the intertidal zone of the Río de la Plata faithfully respond not only to natural gradients, typical of estuaries, but also to the changes introduced by human activity. On the other hand, the trophic importance of benthic diatoms in this ecosystem highlights the need for further taxonomic and ecophysiological studies and extends the study area towards the outer estuary area, which will provide a broader database to infer environmental conditions.

Acknowledgements. Financial support for this study was provided by grants CONICET-PIP 2005-2007 Res. 1556 and PICT 32077, 2007-2010. We thank the anonymous reviewers for improvements to this manuscript, and to oceanographer A. Bianchi for help in data analysis. We are indebted to M. Caviglia for kindly helping with the English translation of this manuscript and to D. F. Haggerty, a retired career investigator and native English speaker, for editing the final draft. This is ILPLA Scientific Contribution No. 874

\section{LITERATURE CITED}

Admiraal W (1984) The ecology of estuarine sediment-inhabiting diatoms. Prog Phycol Res 3:269-322

APHA (American Public Health Association) (1998) Standard methods for examination of water and wastewater, 20th edn. APHA, American Water Works Association, and Water Pollution Control Federation, Washington, DC

Anderson NJ, Vos P (1992) Learning from the past: diatoms as palaeoecological indicators of changes in marine environments. Neth J Aquat Ecol 26:19-30

Battarbee RW, Donald FC, Dixit SS, Renberg I (1999) Diatoms as indicators of surface water acidity. In: Stoermer F, Smol JP (eds) The diatoms: applications for the environmental and earth sciences. Cambridge University Press, Cambridge, p 85-127

Carpelan LH (1978) Evolutionary euryhalinity of diatoms in changing environments. Nova Hedwigia 29:489-526

Charles DF, Smol JP, Engstrom DR (1994) Paleolimnological approaches to biological monitoring. In: Loeb SL, Spacies A (eds) Biological monitoring of aquatic systems. CRC Press, Boca Raton, FL, p 233-292

Clarke AL, Weckström K, Conley DJ, Anderson NJ and others (2006) Long-term trends in eutrophication and nutrients in the coastal zone. Limnol Oceanogr 51:385-397

Cooper SR (1995) Chesapeake Bay watershed historical land use: impact on water quality and diatom communities. Ecol Appl 5:703-723

Cooper SR (1999) Estuarine paleoenvironmental reconstructions using diatoms. In: Stoermer F, Smol JP (eds) The diatoms: applications for the environmental and earth sciences. Cambridge University Press, Cambridge, p 374-388
Denys L, de Wolfs H (1999) Diatoms as indicators of coastal paleoenvironments and relative sea-level change. In: Stoermer F, Smol JP (eds) The diatoms: applications for the environmental and earth sciences. Cambridge University Press, Cambridge, p 277-297

Framiñan MB, Etala MP, Acha EM, Guerrero RA, Lasta CA, Brown OB (1999) Physical characteristics and processes of the Río de la Plata estuary. In: Perillo GME, Piccolo MC, Pino-Quivira M (eds) Estuaries of South America: their geomorphology and dynamics. Springer, Berlin, p 161-194

Frenguelli J (1941) Diatomeas del Río de la Plata. Rev Mus La Plata Nueva Ser Secc Bot III:213-334

Gómez N, Licursi M (2001) The Pampean diatom index (IDP) for assessment of rivers and streams in Argentina. Aquat Ecol 35:173-181

Gómez N, Licursi M, Hualde P (2003) Epiphytic algae on Scirpus californicus (Mey) Sójak in the Río de la Plata (Argentina): structure and architecture. Arch Hydrobiol 14:231-247

Gómez N, Licursi M, Cochero J (2009) Seasonal and spatial distribution of the microbenthic communities of the Rio de la Plata estuary (Argentina) and possible environmental controls. Mar Pollut Bull 58:878-887

$>$ Hassan SG, Espinosa MA, Isla FI (2009) Diatom-based inference model for paleosalinity reconstructions in estuaries along the northeastern coast of Argentina. Palaeogeogr Palaeoclimatol Palaeoecol 275:77-91

Hoffman G (1994) Aufwuchs-Diatomeen in Seen und ihre Eignung als Indikatoren der Trophie. Bibl Diatomol 30: $1-241$

Krammer K (1992) Pinnularia: eine Monographie der europäischen Taxa. Bibl Diatomol 26:1-353

Krammer K (2000) The genus Pinnularia. In: Lange-Bertalot H (ed) Diatoms of Europe, Vol 1. A.R.G. Gantner Verlag, Ruggell

Krammer K, Lange-Bertalot H (1986) Bacillariophyceae Teil 1: Naviculaceae. In: Ettl H, Gerloff J, Heynig H, Mollenhauer D (eds) Süsswasserflora von Mitteleuropa, Vol 2. Gustav Fischer Verlag, Stuttgart

Krammer K, Lange-Bertalot H (1988) Bacillariophyceae Teil 2: Bacillariaceae, Epthemiaceae, Surirellaceae. In: Ettl H, Gerloff J, Heynig H, Mollenhauer D (eds) Süsswasserflora von Mitteleuropa, Vol 2. Gustav Fischer Verlag, Stuttgart

Krammer K, Lange-Bertalot H (1991a) Bacillariophyceae Teil 3: Centrales, Fragilariaceae, Eunotiaceae. In: Ettl H, Gerloff J, Heynig H, Mollenhauer D (eds) Süsswasserflora von Mitteleuropa, Vol 2. Gustav Fischer Verlag, Stuttgart

Krammer K, Lange-Bertalot H (1991b) Bacillariophyceae Teil 4: Achnanthaceae, Literaturverzeichnis. In: Ettl $\mathrm{H}$, Gerloff J, Heynig H, Mollenhauer D (eds) Süsswasserflora von Mitteleuropa, Vol 2. Gustav Fischer Verlag, Stuttgart

Lange-Bertalot H (1979) Pollution tolerance of diatoms as criterion for water quality estimation. Nova Hedwigia 64: 285-304

Licursi M (2005) Efectos de las perturbaciones antropogénicas sobre la taxocenosis de diatomeas bentónicas en sistemas lóticos pampeanos. $\mathrm{PhD}$ dissertation, Universidad Nacional de la Plata, La Plata

Licursi M, Gómez N (2002) Benthic diatoms and some environmental conditions in three lowland streams. Ann Limnol 38:109-118

López C, Nagy G (2005) Cambio global, evolución del estado trófico y floraciones de cianobacterias en el Río de la Plata. In: Barros B, Menéndez A, Nagy G (eds) El cambio climático en el Río de la Plata. CIMA, Buenos Aires p 157-166 
Mackereth FJH, Heron J, Talling JF (1978) Water analysis: some revised methods for limnologists. Scientific Publication 36, Freshwater Biological Association, Ambleside

Mianzan H, Lasta C, Acha E, Guerrero R, Macchi G, Bremec C (2001) The Río de la Plata estuary, Argentina-Uruguay. In: Seeliger U, Kjerfve B (eds) Coastal marine ecosystems of Latin America. Ecological studies, Vol 144. Springer Verlag, Berlin, p 185-204

Muylaert K, Sabbe K, Vyverman W (2000) Spatial and temporal dynamics of phytoplankton communities in a freshwater tidal estuary (Schelde, Belgium). Estuar Coast Shelf Sci 50:673-687

Ohrel RL, Register KM (eds) (2006) Voluntary estuary monitoring manual. EPA-842-B-06-00. Environmental Protection Agency. Available at www.epa.gov/owow/estuaries/ monitor/

Patrick R, Reimer CW (1966) The diatoms of the United States, exclusive of Alaska and Hawaii. Monogr Acad Nat Sci Phila 13 Vol 1

Patrick R, Reimer CW (1975) The diatoms of the United States, exclusive of Alaska and Hawaii. Monogr Acad Nat Sci Phila 13 Vol 2

Potapova M, Charles DF (2003) Distribution of benthic

Editorial responsibility: Hans Heinrich Janssen, Oldendorf/Luhe, Germany diatoms in U.S. rivers in relation to conductivity and ionic composition. Freshw Biol 48:1311-1328

Sládeček V (1973) System of water quality from the biological point of view. Arch Hydrobiol Beih Ergeb Limnol 7:1-218

Sládeček V (1985) Scale of saprobity. Verh Int Verein Limnol 22:2337-2341

Snoeijs P (1999) Applied diatom studies in estuaries and shallow coastal. In: Stoermer F, Smol JP (eds) The diatoms: applications for the environmental and earth sciences. Cambridge University Press, Cambridge, p 298-333

Stoermer EF, Smol JP (eds) (1999) The diatoms: applications for the environmental and earth sciences. Cambridge University Press, Cambridge

Sullivan MJ (1999) Applied diatom studies in estuaries and shallow coastal. In: Stoermer F, Smol JP (eds) The diatoms: applications for the environmental and earth sciences. Cambridge University Press, Cambridge, p 352-373

ter Braak CJF, Verdonschot PFM (1995) Canonical correspondence analysis and related multivariate methods in aquatic ecology. Aquat Sci 57:255-289

Van Dam H, Mertens A, Sinkeldam J (1994) A coded checklist and ecological indicator values of freshwater diatoms from The Netherlands. Neth J Aquat Ecol 28:117-133

Submitted: November 13, 2009; Accepted: October 7, 2010 Proofs received from author(s): November 10, 2010 